of the research and development programme for natural rubber carried out by the Rubber Research Institute of Malaya, the Natural Rubber Producers' Research Association and the Natural Rubber Bureau. Dr. Bateman was educated at Bishopshalt School, Uxbridge, and University College, London, whore he gained honours in chemistry in 1935 and a Ph.D. in 1938, when he also won the Ramsey Memorial Prize for best student of the year. His postgraduate career included service as research assistant under Sir Christopher Ingold and Prof. E. D. Hughes and a senior studentship granted by the Department of Scientific and Industrial Research, held at Oriel College, Oxford, under Sir Robert Robinson. He received a D.Sc. at the University of London in 1955. He joined the then British Rubber Producers' Research Association as a physical chemist in 1941, and was promoted superintendent of chemical research in 1951, becoming acting director in 1953, and finally director of research in April 1954. Dr. Bateman has served the interests of the Natural Rubber Producers of Malaya for more than twenty years, and has been particularly successful in gathering around him a keen, enthusiastic and highly qualified staff at the Natural Rubber Producers' Research Association Laboratories at Welwyn Garden City, Herts. Dr. L. Mullins, at present deputy director of research at the Natural Rubber Producers' Research Association, will act as director during Dr. Bateman's absence, which will be for three years in the first instance.

\section{Council for Scientific and Industrial Research}

Three new members of the Council for Scientific and Industrial Research have recently been appointed by the Minister for Science: Mr. W. J. Carron, president of the Amalgamated Engineering Union; Dr. S. C. Curran, principal of the Royal College of Science and Technology, Glasgow; and Dr. C. Sykes, deputy chairman and managing director of Thos. Firth and John Brown, Ltd., Sheffield. They succeed the following, who have completed their term of office: Mr. L. T. Wright, general secretary of the Amalgamated Weavers Association; Dr. C. J. Smithells, past chairman of Magnesium Elektron, Ltd.; and Prof. B. Bleaney, professor of experimental philosophy in the University of Oxford, who has resigned from the Council on receiving a year's appointment at the University of Pittsburg.

The present constitution of the Council is: Sir Harold Roxbee Cox (chairman), Mr. L. H. Bedford, Mr. W. J. Carron, Prof. C. F. Carter, Dr. J. W. Cook, Mr. Frank Cousins, Dr. S. C. Curran, Mr. G. B. R. Feilden, Prof. E. R. H. Jones, Vice-Admiral Sir Frank Mason, Sir Harry Melville, Prof. O. A. Saunders, Dr. C. Sykes and Mr. H. C. Tett.

\section{Royal Society Visiting Professorships}

Prof. R. Dutakeco, professor of virology, Division of Biology, California Institute of Technology, Pasadena, California, has been appointed Royal Society visiting professor for the academic year 1963-64. $\mathrm{He}$ is expected to take up the appointment in October 1963 and to work in the Departments of Genetics and of Virology at the University of Glasgow. Prof. Dulbecco is a leading virologist and has been the person chiefly responsible for the introduction of the quantitative analytical approach in the study of animal viruses. His interests lie in the three fields of virology, molecular biology and geneties.
The Royal Society and the Leverhulme Trust have established a scheme for the appointment of two visiting professors to India each year. Each visiting professor will visit a university or research institution in India for a period of about four months. It is hoped that in this way a contribution to higher education in India can be made. In implementing the scheme a committee in India will nominate the universities or other institutions to be visited; appointments will be made by the Council of the Royal Society, the finance and administrative arrangements being provided by the Leverhulme Trust Fund. The first appointments will be made so that the visiting professors can be in India during October 1963February 1964.

\section{The International Centre for Advanced Mediter- ranean Agronomic Studies}

ON October 3, the Bari (Italy) Institute of the International Centre for Advanced Mediterranean Agronomic Studies, which was established under the ægis of the Organization for European Co-operation and Development and the Council of Europe, was officially opened. An inaugural lecture, on "International Co-operation and Economic Development", was given by the Italian Minister, Prof. Giuseppe Medici. The new buildings of the Bari Mediterranean Agronomic Institute, which have been built by the Italian Government, were officially opened on the same occasion. Forty students from countries in the Mediterranean area (Cyprus, France, Greece, Israel, Italy, Jordan, Malta, Morocco, Portugal, Spain, Syria, Turkey, Yugoslavia) are to attend the courses this year. Ten of them hold scholarships awarded by the Organization for European Co-operation and Development to nationals of member countries in the process of development. The others have received scholarships from the French and Italian Governments.

\section{Cardio-respiratory Disease Research Project}

THE London School of Hygiene and Tropical Medicine is to undertake a long-term research project on personal and environmental factors in cardiorespiratory diseases, including lung cancer, chronic bronchitis and coronary heart disease. The project has the support of the Tobaceo Manufacturers' Standing Committee, which is to contribute up to $£ 50,000$ a year for ten years. This will also allow for a permanent endowment for the development of epidemiological studies at the School. The research project will have three main aims : (1) to investigate the various environmental factors, such as social, domestic and atmospheric conditions, affecting the onset and evolution of the commoner cardio-respiratory diseases; (2) to identify those physical and psychological characteristics, personal habits and those features of previous medical history which indicate a special predisposition to these diseases; (3) to study the interactions between these several factors, whether personal or external, in the production of cardio-respiratory disease.

It is planned to carry out surveys of the habits, health history and living conditions of different samples of the British population and to conduct physical examinations in smaller groups of individuals co-operating in this work. The later medical history of those taking part will then be carefully studied over a period of years. The whole project may take as long as ten years to complete, but some provisional results can be expected after four or five years. The 